\title{
Workshop Penggunaan Google Formulir sebagai Media Evaluasi Pembelajaran Digital selama Pandemi COVID-19
}

\author{
Sri Wahyuni ${ }^{1}$, Estika Satriani ${ }^{2}$, Fauzul Etfita ${ }^{3}$ \\ Pendidikan Bahasa Inggris, Fakultas Keguruan dan Ilmu Pendidikan, Universitas Islam Riau \\ wahyunis@edu.uir.ac.id \\ 2estikasatriani@edu.uir.ac.id \\ ${ }^{3}$ fauzuletfita@edu.uir.ac.id
}

\begin{abstract}
ABSTRAK
Evaluasi merupakan bagian yang sangat krusial pada proses pembelajaran untuk mengetahui ketercapaian tujuan pembelajaran. Namun, pandemi COVID-19 tidak memungkinkan untuk melaksanakan tes secara konvensional. Untuk mengatasai masalah tersebut, tim pengabdian Program Studi Pendidikan Bahasa Inggris menawarkan solusi dengan memanfaatkan Google formulir sebagai alat tes agar lebih efektif dan efisien di tengah pandemi. Sararan dari pelaksanaan kegiatan pengabdian adalah guru-guru mata pelajaran Bahasa Inggris SMA Negeri 1 Peranap. Kegiatan dilaksanakan secara daring. Setelah materi dipaparkan melalui video tutorial, pemateri melakukan pendampingan mengenai penggunaan Google Formulir dalam evaluasi pembelajaran. Hasil dari kegiatan adalah Guru-guru mendapatkan dampak positif dari kegiatan workshop tes digital melalui Google Formulir $(68,5 \%)$ dan dapat membuat soal melalui Google Formulir (94,7\%).
\end{abstract}

Kata kunci: Evaluasi, COVID-19, Google Formulir, Tes Digital

\section{ABSTRACT}

Evaluation is a very crucial part of the learning process to see the achievement of learning objectives. However, the COVID-19 pandemic does not support carrying out conventional testing. To overcome this problem, the English Education Study Program service team offered a solution using Google Forms as a test tool to make it more effective and efficient during a pandemic. The target of the implementation of community service activities is the English teachers of SMA Negeri 1 Peranap. Activities carried out virtually. After the material was presented through video tutorials, the presenters assisted with using Google Forms in learning evaluation. The result of the activity was that teachers positively impacted the digital test workshop activities through Google Forms (68.5\%) and were able to make questions through Google Forms (94.7\%).

Keywords: Evaluation, COVID-19, Google form, Digital Test

\section{PENDAHULUAN}

Evaluasi merupakan bagian dari proses pembelajaran yang tidak dapat dipisahkan dari kegiatan proses pembelajaran. Pelaksanaan evaluasi yang dilaksanakan dalam kegiatan pembelajaran memiliki peran yang sangat krusial karena evaluasi merupakan indikator atau tahapan untuk melihat sejauh mana keberhasilan yang telah dicapai oleh peserta didik atas bahan ajar atau materi-materi yang telah diajarkan. Selain itu, hasil evaluasi dapat menjadi pedoman ataupun feedback bagi guru dalam mendesain pembelajaran selanjutnya. Sehingga dapat ditarik kesimpulan bahwa tujuan pembelajaran dapat dikonfirmasi akurat dengan adanya evaluasi pembelajaran.

Lebih lanjut, evaluasi merupakan langkah yang dilaksanakan untuk mengukur keberhasilan tujuan-tujuan pembelajaran yang telah didesain serta menilai proses pelaksanaan pembelajaran secara holistik. Evaluasi bukan hanya semata-mata untuk menilai suatu aktifitas secara impulsif dan situasional, melainkan merupakan kegiatan untuk menilai kesuksesan pembelajaran secara terorganisasi, sistematik, dan terarah berdasarkan sasaran yang jelas (Rusman et al., 2011).

Namun, selama masa pandemi COVID19 guru-guru SMA Negeri 1 Peranap mengalami hambatan dalam melakukan evalusi pembelajaran karena evaluasi yang biasanya dilaksanakan secara luring bertransfromasi menjadi daring. Berdasarkan interviu dengan kepada sekolah dan berberapa guru di SMA Negeri 1 Peranap beberapa masalah yang dihadapi dalam melaksanakan evalusi pembelajaran adalah; (1) guru sulit memeriksa softcopy lembar kerja peserta didik; (2) guru 
sulit memberikan skor dan membutuhkan waktu yang lama dalam memberikan umpan balik pada lembar kerja peserta didik; dan (3) guru membutuhkan edukasi terkait media untuk evaluasi pembelajaran digital sehingga memudahkan bagi guru maupun peserta didik.

Untuk mengatasai masalah yang sedang dihadapi oleh guru-guru SMA Negeri 1 Peranap yang ditelah dijelaskan, integrasi teknologi menjadi salah satu elemen yang harus dipraktikan dalam proses pembelajaran khususnya evaluasi. Selain itu, proses pembelajaran khususnya evaluasi menjadi lebih efektif dan efisien dengan memanfaatkan teknologi yang ada. Sebagaimana disimpulkan dari beberapa hasil penelitian yang menyebutkan bahwa perkembangan teknologi menggiring perubahan praktek pembelajaran yang tidak terbatas ruang dan waktu (Arigusman et al., 2018; Suherdi, 2019). Terlebih lagi pada masa pandemi COVID-19, Perubahan atmosfir pembelajaran dari offline menjadi online ini menciptakan tantangan dan tuntutan berinovasi dalam pengajaran (Suherdi \& Mian, 2017).

Salah satu platform yang dapat digunakan secara gratis dalam merancang kuis digital adala Google Formulir. Platform ini sangat mudah dan ramah diakses oleh users. Beberapa penelitian sebelumnya mengungkapkan seperti Batubara (2016) meneliti mengenai Penggunaan Google Form sebagai Alat Penilaian Kinerja Dosen di Program Studi PGMI UNISKA Muhammad Arsyad Al Banjari yang mengungkapkan bahwa kepuasan mahasiswa dan dosen dalam menggunakan Google Formulir untuk menilai kinerja dosen karena mudah diakses, hemat waktu dan hemat kertas. Pernyataan tersebut juga didukung oleh Rahardja et al. (2018) juga mengkaji mengenai Pemanfaatan Google Formulir sebagai Sistem Pendaftaran Anggota pada Website Aptisi.or.id yang menunjukan adanya perubahan system pendaftaran secara daring yang lebih efisien.

Berdasarkan urgensi dan latar belakang masalah yang telah dipaparkan, Dosen Program Studi Pendidikan Bahasa Inggris FKIP UIR melaksanakan kegiatan Pengabdian kepada Masyarakat (PkM) dengan judul "Workshop Penggunaan Google Formulir sebagai Media Evaluasi Pembelajaran Digital”.

\section{METODE KEGIATAN}

Sararan dari pelaksanaan kegiatan pengabdian adalah guru-guru mata pelajaran Bahasa Inggris SMA Negeri 1 Peranap. Metode yang digunakan dalam kegiatan PkM ini adalah pelatihan dan pendampingan secara virtual. Adapun beberapa langkah-langkah teknis yang dilaksanakan adalah dalam bentuk: 1. Ceramah; 2. Tanya Jawab; 3. Diskusi; 4. Latihan dan pembimbingan. Selanjutnya, skema kegiatan PkM yang akan dilaksanakan divisualisasikan pada gambar 1 . Metode penyampaian materi workshop dilaksanakan secara virtual melalui video tutorial.

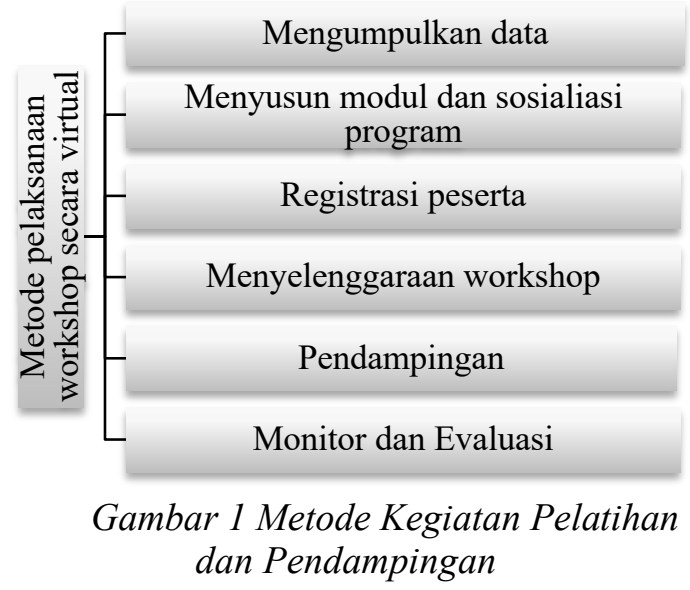

Untuk mengukur ketercapaian kegiatan Pengabdian kepada Masyarakat (PkM) yang akan dilaksanakan, digunakan beberapa intrumen. Beberapa instrumen yang digunakan adalah observasi, angket, dan analisis dokumen hasil implementasi merancang tes digital melalui Google Formulir.

\section{HASIL \& PEMBAHASAN}

Berdasarkan dari tahapan-tahapan pelaksaan yang telah dilaksanakan, hasil kegiatan kegiatan diklasifikasikan berdasarkan formulasi dari kegiatan;1) Bagaimanakah dampak pelaksanaan kegiatan "Workshop Penggunaan Google Formulir sebagai Media Evaluasi Pembelajaran Digital" bagi guru-guru mata pelajaran Bahasa Inggris di SMA Negeri 1 Peranap?; 2) Bagaimana guru-guru mata pelajaran Bahasa Inggris di SMA Negeri 1 Peranap dapat mengimplementasikan perancangan tes digital melalui Google Formulir untuk meningkatkan efektivitas evaluasi pembelajaran?; 3) Bagaimana respon guru-guru mata pelajaran Bahasa Inggris di SMA Negeri 1 Peranap dalam merancang tes digital melalui Google Formulir?. Adapun rincian hasil kegiatan adalah sebagai berikut.

1. Bagaimanakah dampak pelaksanaan kegiatan "Workshop Penggunaan Google Formulir sebagai Media Evaluasi Pembelajaran Digital" bagi guru-guru mata 
pelajaran Bahasa Inggris di SMA Negeri 1 Peranap?

Dampak workshop yang dilaksanakan oleh tim pelaksana secara rinci terkait dengan penggunaan Google Formulir sebagai media evaluasi pembelajaran digital dapat dilihat pada tabel 1 berikut ini.

Tabel 1. Dampak Pelaksanaan Kegiatan “Workshop Penggunaan Google Formulir sebagai Media Evaluasi Pembelajaran Digital”

\begin{tabular}{|c|l|c|c|c|c|}
\hline \multirow{2}{*}{ No } & \multicolumn{1}{|c|}{ Pernyataan } & \multicolumn{3}{c|}{ Persentase Respon } \\
\cline { 3 - 6 } & & SS & S & TS & STS \\
\hline 1 & Materi PkM sesuai dengan kebutuhan Mitra/Peserta & $69.8 \%$ & $30.3 \%$ & 0 & 0 \\
\hline 2 & Kegiatan PkM yang dilaksanakan sesuai harapan Mitra & $68.4 \%$ & $31.6 \%$ & 0 & 0 \\
\hline 4 & Cara pemateri menyajikan materi PkM menarik & $69.8 \%$ & $28.9 \%$ & $1.3 \%$ & 0 \\
\hline 5 & Materi yang disajikan jelas dan mudah dipahami & $69.8 \%$ & $28.9 \%$ & 0 & 0 \\
\hline 5 & $\begin{array}{l}\text { Waktu yang disediakan sesuai untuk penyampaian materi } \\
\text { dan kegiatan PkM }\end{array}$ & $61.8 \%$ & $36.8 \%$ & $1.3 \%$ & 0 \\
\hline 6 & $\begin{array}{l}\text { Mitra berminat untuk mengikuti kegiatan PkM selama } \\
\text { sesuai kebutuhan Mitra/peserta }\end{array}$ & $57.9 \%$ & $42.1 \%$ & 0 & 0 \\
\hline 7 & $\begin{array}{l}\text { Anggota PkM yang terlibat dalam kegiatan pengabdian } \\
\text { masyarakat memberikan pelayanan sesuai dengan } \\
\text { kebutuhan }\end{array}$ & $63.2 \%$ & $36.8 \%$ & 0 & 0 \\
\hline 8 & Kegiatan PkM dilakukan secara berkelanjutan & $69.8 \%$ & $30.3 \%$ & 0 & 0 \\
\hline 9 & $\begin{array}{l}\text { Setiap keluhan/pertanyaan/permasalahan yang diajukan } \\
\text { ditindaklanjuti dengan baik oleh narasumber/anggota } \\
\text { pengabdian yang terlibat }\end{array}$ & $68.5 \%$ & $30.3 \%$ & $1.3 \%$ & 0 \\
\hline 10 & $\begin{array}{l}\text { Mitra mendapatkan manfaat langsung dari kegiatan PkM } \\
\text { yang dilaksanakan }\end{array}$ & $64.5 \%$ & $35.5 \%$ & 0 & 0 \\
\hline 11 & $\begin{array}{l}\text { Kegiatan PkM berhasil meningkatkan } \\
\text { kesejahteraan/kecerdasan mitra }\end{array}$ & $64.5 \%$ & $35.5 \%$ & 0 & 0 \\
\hline 12 & Secara Umum, mitra puas terhadap kegiatan PkM & $68.5 \%$ & $31.6 \%$ & 0 & 0 \\
\hline
\end{tabular}

Tabel 1 menunjukkan bahwa pelaksanaan workshop memberikan dampak positif bagi guru-guru di SMAN 1 Peranap. Dampak positif tersebut dapat dilihat dari kebutuhan peserta, kesesuaian materi, metode penyampaian, waktu penyampaian, tindak lanjut, manfaat, dan tingkat kepuasan peserta. Terkait dengan kebutuhan peserta untuk mengikuti kegiatan, $57,9 \%$ peserta memilih "sangat setuju" $69,8 \%$ peserta memilih "sangat setuju" untuk kesesuaian materi yang dipaparkan oleh tim pelaksana serta materi yang disajikan menarik, jelas, dan mudah dipahami. Senada dengan pernyataan Setemen (2010) \& Zahara (2015) Untuk dapat melaksanakan evaluasi pembelajaran yang efisien dan efektif di masa pandemi COVID19, perlu diterapkan evaluasi pembelajaran berbasis website atau evaluasi pembelajaran digital.

Selanjutnya, $66,7 \%$ peserta memilih "sangat setuju" terkait dengan metode dan waktu penyampaian materi dilaksanakan sudah sesuai dengan harapan peserta. $67,17 \%$ peserta memilih "sangat setuju" terhadap pelayanan yang merupakan bentuk tindak lanjut dari kegiatan. Selanjutnya, 64,5\% peserta percaya kegiatan memberikan konstribusi yang positif. Secara umum, peserta puas terhadap kegiatan yang telah dilaksanakan dengan dibuktikan 68,5\% peserta memilih "sangat setuju". Dampak positif kegiatan juga divisualisasikan pada gambar 2.

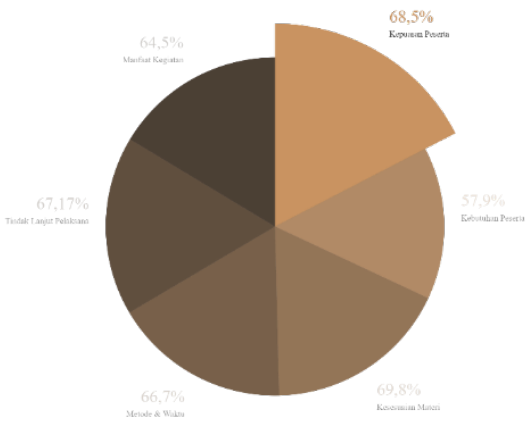

Gambar 2. Dampak Pelaksanaan Kegiatan

"Workshop Penggunaan Google Formulir sebagai Media Evaluasi Pembelajaran Digital” 
2. Bagaimana guru-guru mata pelajaran Bahasa Inggris di SMA Negeri 1 Peranap dapat mengimplementasikan perancangan tes digital melalui Google Formulir untuk meningkatkan efektivitas evaluasi
Implementasi perancangan tes digital melalui Google Formulir sebagai media evaluasi pembelajaran digital dapat dilihat pada tabel 2 berikut ini. pembelajaran?

Tabel 2 Impelmentasi Workshop

\begin{tabular}{|c|c|c|c|}
\hline No & Tahapan & 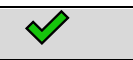 & $x$ \\
\hline 1 & Peserta memiliki akun google atau gmail & $98.7 \%$ & $1.3 \%$ \\
\hline 2 & $\begin{array}{l}\text { Peserta masuk ke Google Drive lalu mengklik tombol New } \\
>\text { More }>\text { Google forms }>\text { Blank Form }\end{array}$ & $87.4 \%$ & $2.6 \%$ \\
\hline 3 & $\begin{array}{l}\text { Peserta mengganti judul sesuai dengan kebutuhan misal "Soal } \\
\text { Latihan Bahasa Inggris" }\end{array}$ & $93.4 \%$ & $6.6 \%$ \\
\hline 4 & $\begin{array}{l}\text { Peserta dapat mengganti warna latar dengan mengklik fitur } \\
\text { background. }\end{array}$ & $89,5 \%$ & $10,5 \%$ \\
\hline 5 & Peserta mulai membuat pertanyaan pada bagian pertama. & $94,7 \%$ & $5,3 \%$ \\
\hline 6 & Perserta menambahkan pertanyaan selanjutnya. & $89,5 \%$ & $10,5 \%$ \\
\hline 7 & Peserta juga dapat menambahkan section baru. & $89,5 \%$ & $10,5 \%$ \\
\hline 8 & Peserta menambahkan judul pada fitur title. & $93,4 \%$ & $6,6 \%$ \\
\hline 9 & $\begin{array}{l}\text { Menambahkan pertanyaan dengan mengklik ikon }+ \text { pada } \\
\text { layar. }\end{array}$ & $86,8 \%$ & $13,2 \%$ \\
\hline 10 & $\begin{array}{l}\text { Peserta memasukkan kunci jawaban sesuai ikon yang muncul } \\
\text { pada layar. }\end{array}$ & $93,4 \%$ & $6,6 \%$ \\
\hline 11 & $\begin{array}{l}\text { Peserta dapat menambahkan gambar sesuai dengan } \\
\text { kebutuhan dengan upload gambar. }\end{array}$ & $94,7 \%$ & $5,3 \%$ \\
\hline 12 & $\begin{array}{l}\text { Peserta dapat membuat fitur untuk menyimpan respon atau } \\
\text { tanggapan atau jawaban user. }\end{array}$ & $89,5 \%$ & $10,5 \%$ \\
\hline 13 & $\begin{array}{l}\text { Selanjutnya, membuat pratinjau untuk memeriksa hasil } \\
\text { rancangan dan memastikan semua pertanyaan dan setting } \\
\text { sudah sesuai dengan yang diharapkan yaitu mengklik ikon } \\
\text { mata pada layar. }\end{array}$ & $88,2 \%$ & $11,8 \%$ \\
\hline 14 & $\begin{array}{l}\text { Peserta dapat mengirim tautan online test dengan mengklik } \\
\text { tulisan "kirim" atau "send". }\end{array}$ & $93,4 \%$ & $6,6 \%$ \\
\hline 15 & $\begin{array}{l}\text { Peserta juga dapat menganalisis jawaban user dengan melihat } \\
\text { analisis hasil jawaban user. }\end{array}$ & $93,4 \%$ & $6,6 \%$ \\
\hline
\end{tabular}

Pada tabel 2 dapat dilhat, guru-guru dapat mengimplementasikan Google formulir sebagai alat tes digital karena 98,7\% guru telah memiliki akun google. Selama proses pembuatan tes digital, guru mampu memanfaatkan setiap fitur yang terdapat pada Google formulir. Hal ini dibuktikan dengan guru dapat menganti latar belakang soal $(89,5 \%)$, guru mulai membuat pertanyaan pada bagian pertama $(94,7 \%)$, guru dapat menambahkan pertanyaan selanjutnya dan menambahkan section baru (89,5\%), guru dapat memasukkan kunci jawaban $(93,4 \%)$, guru dapat membuat pratinjau untuk memeriksa hasil rancangan $(88,2 \%)$, dan guru dapat mengirim tautan online tes $(93,4 \%)$. Dipertegas juga oleh Castro (2018) bahwa Google formulir kompatibel untuk pemula. Selanjutnya, ditambahkan oleh Raju \& Harinarayana (2016) yang menyatakan bahwa fitur Google formulir lebih lengkap dibanding media evaluasi digital lainnya. Implementasi perancangan tes digital juga divisualisasikan pada gambar 3 .

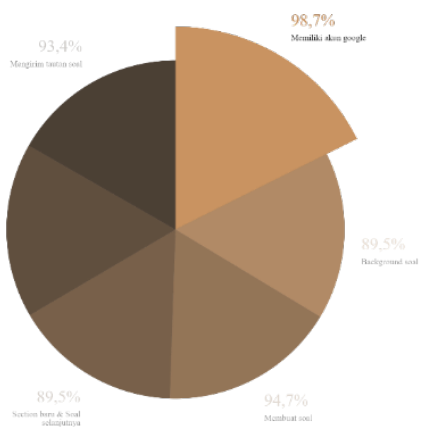

Gambar 3 Implementasi perancangan tes digital dengan Google Formulir 
3. Bagaimana respon guru-guru mata pelajaran Bahasa Inggris di SMA Negeri 1 Peranap dalam merancang tes digital melalui Google Formulir?
Respon guru atau peserta terhadap kegiatan tes digital melalui Google Formulir sebagai media evaluasi pembelajaran digital dapat dilihat pada tabel 3 berikut ini.

Tabel 3 Angket Respon Guru Terhadap Implemntasi tes digital melalui Google Formulir

\begin{tabular}{|c|c|c|c|c|c|c|c|}
\hline \multirow{2}{*}{ No } & \multirow{2}{*}{ Pertanyaan } & 1 & 2 & 3 & 4 & 5 & 6 \\
\hline & & \multicolumn{5}{|l|}{ STS } & SS \\
\hline 1 & $\begin{array}{l}\text { Lebih hemat dan efisien dari segi materi } \\
\text { dan waktu daripada membuat soal }\end{array}$ & 0 & 0 & $2,6 \%$ & $7,9 \%$ & $48,7 \%$ & $40,8 \%$ \\
\hline 2 & $\begin{array}{l}\text { Lebih mudah menerapkannya karena fitur- } \\
\text { fitur Google Form tidak terlalu rumit. }\end{array}$ & 0 & 0 & $2,6 \%$ & $10,5 \%$ & $46,1 \%$ & $40,8 \%$ \\
\hline 3 & $\begin{array}{l}\text { Membuat guru lebih praktis dalam } \\
\text { memeriksa jawaban siswa. }\end{array}$ & 0 & 0 & $1,3 \%$ & $9,2 \%$ & $39,5 \%$ & $50 \%$ \\
\hline 4 & $\begin{array}{l}\text { Membuat guru lebih melek teknologi } \\
\text { informasi khususnya aplikasi-aplikasi } \\
\text { vang membantu proses belaiar mengaiar. }\end{array}$ & 0 & 0 & $1,3 \%$ & $6,6 \%$ & $35,5 \%$ & $56,5 \%$ \\
\hline 5 & $\begin{array}{l}\text { Mengembangkan kreatifitas guru untuk } \\
\text { membuat soal. }\end{array}$ & 0 & 0 & $2,6 \%$ & $6,6 \%$ & $36,8 \%$ & $53,9 \%$ \\
\hline 6 & $\begin{array}{l}\text { Melatih guru memberikan penilaian dan } \\
\text { umpan balik secara langsung dan rinci }\end{array}$ & 0 & 0 & $2,6 \%$ & $10,5 \%$ & $36,8 \%$ & $50 \%$ \\
\hline 7 & $\begin{array}{l}\text { Memberikan kesempatan kepada guru } \\
\text { untuk belajar menjadi evaluator yang baik }\end{array}$ & 0 & 0 & $1,3 \%$ & $7,9 \%$ & $38,2 \%$ & $52,6 \%$ \\
\hline 8 & $\begin{array}{l}\text { Berhasil hanya jika guru memiliki akses } \\
\text { internet di rumah. }\end{array}$ & $1,3 \%$ & $2,6 \%$ & $5,3 \%$ & $14,5 \%$ & $38,2 \%$ & $38,2 \%$ \\
\hline 9 & $\begin{array}{l}\text { Sukses hanya jika ada pelatihan guru yang } \\
\text { memadai dalam penggunaan teknologi } \\
\text { untuk belajar. }\end{array}$ & 0 & 0 & $6,6 \%$ & $15,8 \%$ & $39,5 \%$ & $38,2 \%$ \\
\hline 10 & $\begin{array}{l}\text { Membuat guru merasa lebih kompeten } \\
\text { sebagai pendidik. }\end{array}$ & 0 & 0 & $2,6 \%$ & $9,2 \%$ & $32,9 \&$ & $55,3 \%$ \\
\hline 11 & $\begin{array}{l}\text { Terlalu mahal dalam hal sumber daya, } \\
\text { waktu dan usaha. }\end{array}$ & $6,6 \%$ & $3,9 \%$ & $11,8 \%$ & $19,7 \%$ & $32,9 \%$ & $25 \%$ \\
\hline 12 & $\begin{array}{l}\text { Sukses hanya jika pihak sekolah } \\
\text { mendukung jaringan internet di sekolah. }\end{array}$ & $1,3 \%$ & $1,3 \%$ & $7,9 \%$ & $19,7 \%$ & $32,9 \%$ & $36,8 \%$ \\
\hline 13 & $\begin{array}{l}\text { Menuntut terlalu banyak waktu karena } \\
\text { masalah teknis. }\end{array}$ & $3,9 \%$ & $2,6 \%$ & $11,8 \%$ & $21,1 \%$ & $35,5 \%$ & $25 \%$ \\
\hline 14 & $\begin{array}{l}\text { Belum dapat diterapkan di sekolah karena } \\
\text { kurangnya fasilitas. }\end{array}$ & $1,3 \%$ & $3,9 \%$ & $11,8 \%$ & $26,3 \%$ & $27,6 \%$ & $28,9 \%$ \\
\hline 15 & $\begin{array}{l}\text { Dapat menghemat biaya ujian di sekolah } \\
\text { apabila diterapakan di ujian akhir sekolah. }\end{array}$ & $1,3 \%$ & 0 & $3,9 \%$ & $6,6 \%$ & $42,1 \%$ & $46.1 \%$ \\
\hline 16 & $\begin{array}{l}\text { Jika dikelola dengan baik oleh guru dan } \\
\text { pihak sekolah dapat menjadi bank soal. }\end{array}$ & 0 & 0 & $5,3 \%$ & $7,9 \%$ & $38,2 \%$ & $48,7 \%$ \\
\hline 17 & $\begin{array}{l}\text { Memudahkan guru \& sekolah melakukan } \\
\text { penilaian \& pendataan rata-rata } \\
\text { kemampuan siswa lebih cepat. }\end{array}$ & 0 & 0 & $2,6 \%$ & $7,9 \%$ & $38,2 \%$ & $51,3 \%$ \\
\hline 18 & Lebih akurat dalam melakukan penilaian. & 0 & 0 & $6,6 \%$ & $9,2 \%$ & $42,1 \%$ & $42,1 \%$ \\
\hline 19 & $\begin{array}{l}\text { Membutuhkan pelatihan keterampilan } \\
\text { yang terlalu memakan waktu. }\end{array}$ & $3,9 \%$ & $5,3 \%$ & $7,9 \%$ & $18,4 \%$ & $30,3 \%$ & $34,2 \%$ \\
\hline
\end{tabular}




\begin{tabular}{|c|c|c|c|c|c|c|c|}
\hline 20 & $\begin{array}{l}\text { Meningkatkan minat siswa untuk belajar } \\
\text { dan berlatih soal. }\end{array}$ & 0 & 0 & $5,3 \%$ & $17,1 \%$ & $32,9 \%$ & $44,7 \%$ \\
\hline 21 & $\begin{array}{l}\text { Meningkatkan } \\
\text { (misalnya nilai). }\end{array} \quad$ prestasi $\quad$ akademik & 0 & 0 & $2,6 \%$ & $17,1 \%$ & $39,5 \%$ & $40,8 \%$ \\
\hline 22 & $\begin{array}{l}\text { Memotivasi siswa untuk lebih terlibat } \\
\text { dalam kegiatan belajar. }\end{array}$ & 0 & 0 & $5,3 \%$ & $10,5 \%$ & $42,1 \%$ & $42,1 \%$ \\
\hline 23 & $\begin{array}{l}\text { Mengurangi kecurangan (menyontek) } \\
\text { dalam menjawab soal. }\end{array}$ & 0 & $1,3 \%$ & $10,5 \%$ & $11,8 \%$ & $35,5 \&$ & $40,8 \%$ \\
\hline 24 & Mudah bagi siswa untuk mengaksesnya. & 0 & 0 & $3,9 \%$ & $14,5 \%$ & $48,7 \%$ & $32,9 \%$ \\
\hline 25 & $\begin{array}{l}\text { Siswa dapat merasakan manfaat positif } \\
\text { dari penggunaan teknologi informasi. }\end{array}$ & 0 & 0 & $3,9 \%$ & $9,2 \%$ & $39,5 \%$ & $47,4 \%$ \\
\hline
\end{tabular}

Dapat dilihat pada tabel 3, Skala 1 menunjukkan "Sangat tidak setuju", 2 "cukup tidak stuju", 3 "sedikit tidak setuju", 4 "sedikit setuju", 5 "cukup setuju", 6 "sangat setuju". Mayoritas guru merespon cukup setuju dan sangat setuju dengan tes digital melalui Google Formulir. Hal tersebut dapat dibuktikan dengan guru-guru percaya bahwa Google Formulir dapat lebih efisien dan hemat $(48,7 \%)$, lebih mudah $(46,1 \%)$ dan lebih praktis $(50 \%)$ dari pada membuat tes konvensional.

Beberapa pakar telah mengemukakan keuntungan dari menggunakan tes daring atau tes berbasis dgital diantaranya adalah Redecker (2013) secara umum menjelaskan bahawa evaluasi pembelajaran digital meningkatkan efisiensi dan efektifitas ditinjau dari aspek administrasi. Selain itu evaluasi digital juga dapat digunakan untuk meningkatkan validitas dan reliabilitas skor tes. Sementara itu, ditinjau dari aspek siswa, pemanfaatan tes digital dapat meningkatkan motivasi, konsentrasi, dan performance peserta didik. Ditegaskan oleh Bridgeman et al., (2009), tes dalam bentuk digital memberikan keuntungan bagi guru untuk dapat mempersiapkan materi dengan lebih berkualitas sebagai bahan tes dan menghasilkan tes yang ideal serta dapat memonitor dan mendorong peserta didik dalam mengerjakan tes.

Efektifitas Google Formulir sebagai tes digital juga divsualisasi pada gambar 4 .

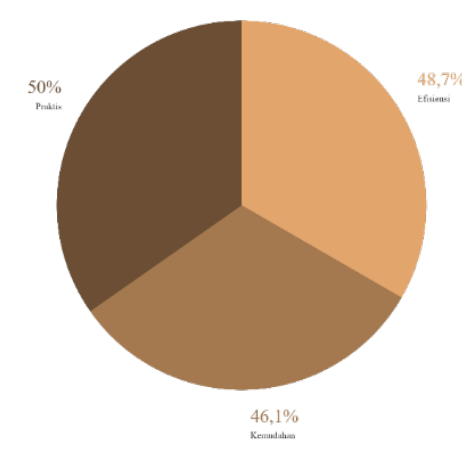
Gambar 4. Efektifitas Google Formulir
sebagai tes digital

\section{KESIMPULAN \& SARAN}

Kesimpulan dari hasil kegiatan workshop Penggunaan Google Formulir sebagai Media Evaluasi Pembelajaran Digital adalah sebagai berikut.

1. Guru-guru mendapatkan dampak positif dari kegiatan workshop tes digital melalui Google Formulir.

2. Guru-guru mata pelajaran Bahasa Inggris di SMA Negeri 1 Peranap dapat mengimplementasikan perancangan tes digital melalui Google Formulir.

3. Guru-guru mata pelajaran Bahasa Inggris di SMA Negeri 1 Peranap memberikan respon yang positif terhadap tes digital melalui Google Formulir.

Untuk memberikan kontribusi terhadap pengembangan ilmu dan mendukung terlaksananya proses pembelajaran dengan maksimal, tim pengabdian menawarkan saran yang diantaranya adalah sebagai berikut.

1. Guru-guru membutuhkan sumber daya pendukung seperti jaringan internet dari pihak sekolah agar pembelajaran yang dilaksanakan secara online selama pandemi dapat dilaksanakan dengan maksimal. 
2. Pihak sekolah merancang koordinator untuk setiap mata pelajaran dan membuat bank soal melalui Google Formulir.

3. Perlu adanya pelatihan keterampilan berkelanjutan terkait pengintegrasian teknologi dalam proses pembelajaran.

\section{DAFTAR PUSTAKA}

Arigusman, A., Purnawarman, P., \& Suherdi, D. (2018). EFL students' use of technology in English lesson in the digital era. Indonesian Journal of Curriculum and Educational Technology Studies, 6(299), 77-86.

Batubara, H. H. (2016). Penggunaan Google Form sebagai alat penilaian kinerja dosen Di Prodi PGMI Uniska Muhammad Arsyad Al Banjari. AL-BIDAYAH, 8(1), 39-50.

Bridgeman, B., Trapani, C., \& Attali, Y. (2009). Considering fairness and validity in evaluating automated scoring. The Annual Meeting of the National Council on Measurement in Education (NCME).

Castro, S. (2018). Google Forms Quizzes and Substitution, Augmentation, Modification, and Redifinition (SAMR) Model Intergration. Issues and Trends in Educational Technology, 6(2), 4-14.

Rahardja, U., Lutfiani, N., \& Alpansuri, M. S. (2018). Pemanfaatan Google Formulir sebagai sistem pendaftaran anggota pada Website Aptisi.or.id. Sisfotenika, 8(2), 128-139.

https://doi.org/10.30700/jst.v8i2.401

Raju, N. V., \& Harinarayana, N. S. (2016). Online survey tools: A case study of Google Forms. The National Conference on Scientific, Computational \& Information Research Trends in Engineering.

Redecker, C. (2013). The use of ICT for the assessment of key competences. Publication Office of the European Union.

Rusman, R., Kurniawan, D., \& Riyana, C. (2011). Pembelajaran Berbasis Teknologi Informasi dan Komunikasi. PT. Raja Grafindo.

Setemen, K. (2010). Pengembangan evaluasi pembelajaran online. Jurnal Pendidikan Dan Pengajaran, 43(3), 207-214.

Suherdi, D. (2019). SMEMFLE I 4.0 DE: A synergetic multi-layered educational model for learning excellence in industry 4.0 and disruption era. 3rd Asian Education Symposium (AES 2018), 253, 439-445.
Suherdi, D., \& Mian, Y. (2017). Towards the establishment of teachers' multicontext information and communication (ICT) training. English Language Teaching and Technology Journal (ELT-Tech Journal), 1(1), 1-11.

Zahara, N. (2015). Evaluasi Pembelajaran Online Berbasis Web Sebagai Alat Ukur Hasil Belajar Siswa Pada Materi Dunia Tumbuhan Kelas X Man Model Banda Aceh. Seminar Nasional Biotik, 480-484. 